\title{
Advantages and challenges for Brazilian export of frozen beef
}

\section{Paulo Rodrigo Ramos Xavier Pereira ${ }^{1,2}$, Júlio Otávio Jardim Barcellos ${ }^{2,5,6}$, Luiz Carlos Federizzi ${ }^{5}$, Vinícius do Nascimento Lampert ${ }^{2,3}$, Maria Eugênia Andrighetto Canozzi ${ }^{2}$, Pedro Rocha Marques ${ }^{2,4}$}

\footnotetext{
1 Universidade Federal do Piauí - Campus Professora Cinobelina Elvas - Bom Jesus (CPCE- UFPI).

2 Núcleo de Estudos em Sistemas de Produção de Bovinos de Corte e Cadeia Produtiva (NESPRO) - UFRGS.

${ }^{3}$ Doutorando em Zootecnia - Faculdade de Agronomia - UFRGS.

${ }^{4}$ Mestrando em Agronegócios (CEPAN) - UFRGS.

${ }^{5}$ Curso de Pós-Graduação em Agronegócios - UFRGS. Pesquisador CNPq.

${ }^{6}$ Curso de Pós-Graduação em Zootecnia - Faculdade de Agronomia - UFRGS.
}

\begin{abstract}
The objectives of this research were to analyse data on the international market of frozen boneless beef and to classify its participants into groups according to their trade relationships, identifying the main factors that influence the preference of a country to beef from a determined supplier country. International beef trade is composed of two markets: in one of them, the relationships between supplier and client depend on the lowest price, and Brazil is found in favorable conditions; and the other, the relationships are preferably based on the sanitary quality of the herd and traceability systems recognized by the purchaser, to which Brazilian participation is low.
\end{abstract}

Key Words: bovine spongiform encephalopaty (BSE), cluster analysis, data mining, foot and mouth disease, international trade beef

\section{Vantagens e desafios para à exportação brasileira de carne bovina congelada}

\begin{abstract}
RESUMO - Os objetivos nesta pesquisa foram analisar os dados referentes ao mercado internacional de carne bovina congelada desossada e classificar seus participantes em grupos de acordo com suas relações comerciais elencando os principais fatores que influenciam a preferência de um país pela carne bovina de determinado país fornecedor. O comércio internacional de carne bovina é composto de dois mercados: num deles as relações entre fornecedor e cliente dependem do menor preço e Brasil encontra-se em condições favoráveis; e no outro as relações se dão preferencialmente em razão da qualidade sanitária do rebanho e de sistemas de rastreabilidade reconhecidos pelo comprador, cuja participação do Brasil é pequena.
\end{abstract}

Palavras-chave: análise de cluster, comércio internacional de carnes, encefalopatia espongiforme bovina (BSE), febre aftosa, mineração de dados

\section{Introduction}

A rapid growth in the beef international market has been observed over the last few years. According to DESA/UNSD (2008), the volume of imports in 2006 was approximately $50 \%$ higher than the volume registered in 1994. During this period, about 53.8 million tons of beef were imported, generating a revenue of approximately US $\$ 160$ billion, out of which 48 million tons and US\$ 143 billion corresponded to fresh meat. Bovine meat is referred to in international commerce as industrialized and fresh, the latter concerns about the product stem from its animal origins that have been through a physiological maturation process in which only conservation by cold is allowed. This commodity is internationally commercialized under bony and boneless forms, which can be chilled or frozen (DESA/UNSD, 2008b). Amongst the types of fresh beef commercialized in international market, $90 \%$ is boneless meat, from which $73 \%$ and $58 \%$ are to frozen product.

In this scenario of growth, the Brazilian agro-industrial beef chain also achieved commercial gains, with an increase of $1,460 \%$ from 1994 to 2006, reaching approximately $28 \%$ of world exportation. In such a period, in all Brazilian beef exports, the product that showed the highest growth in sales to foreign countries was fresh beef, with an increase of more than 110 thousand tons for chilled boneless beef 
(CBB) and about 1 million tons of frozen boneless beef (FBB).

Currently, Brazilian exports correspond to about 31\% of invoicing and $35 \%$ of the volume of frozen boneless beef in international trade. Until recently, the exception was the European Union, which acquired 25\% of Brazilian FBB exports, which corresponds to $38 \%$ of the income obtained by selling this product in the international market. Nevertheless, in the face of nonconformities in the Brazilian system of bovine traceability, the European Union reduced its purchases from Brazil by $80 \%$, leading to a migration of the production surplus to markets with low profitability, such as Russia and Egypt (ALICEWEB, 2008; USDA, 2008).

Despite the loss of market from Brazilian exporters, this study has as the objective to analyze the profile of frozen boneless beef international trade, highlighting the main exporting and importing countries and the possible reasons that lead to a preference for specific suppliers, which generates information pertinent to the discussion of the main factors limiting Brazilian competitiveness in this market.

\section{Material and Methods}

The quantitative data used in the analysis were obtained from DESA/UNSD, which is the statistical basis for commodity trade in the United Nations. The export, import, and reimport registers for hundreds of commodities of various orders, which consist of commercial partners, volumes, and values in American dollars (US\$) of free on board (value received at the original port of the product) involved on transactions reported by nearly 200 countries are available on this guide. The variable used was frozen boneless beef, which was registered in the database under the code 020230 and classification HS 1992, as well as the countries or agents that negotiated such commodity from 1994 to 2006.

As selection criteria, the 10 leading beef exporting countries with higher prevalence at the annual classification of United States Department of Agriculture (USDA) were established. Thus, nine countries and one economical block - due to Common Agricultural Politics (CAP), EU-15 was considered as one country for both export and import -, which originally composed a sample of $95.86 \%$ of the total metric tons of exported beef, were defined for this study (Table 1). As importers, all countries that made frozen boneless beef negotiations next to the ten countries classified as exporters were considered.

Data collection and processing resulted in a chart with six columns with the following variables:
- observation period or year: the sample corresponded to frozen boneless beef exports from 1994 to 2006;

- exporting country: the ten main exporters;

- importing country: countries that imported frozen boneless beef from one or more of the ten exporting countries that compose the sample;

- traded volume: the total exported/imported between two commercial partners. Information originally expressed in $\mathrm{kg}$ and converted to tons;

- invoicing: total obtained in the commercial operation stated above, originally expressed in US\$ and converted into thousands of US\$ (1 000 US\$). Aiming to eliminate an inflation effect, the values were deflated using the producer price index (BLS, 2008);

- prices in US\$ by tons (P\$T): medium or absolute prices obtained by tons for each commercial operation.

A sample adjustment was performed, eliminating the observations in which the volume was lower than the maximal capacity of an 18-metric ton container (ISO, 2008) and the deflation of values in dollars through Producer Price Index (BLS, 2008) as of January, 2007. Such a procedure reduced the number of observations from 6,282 to 5,320, and the total transacted volume by $0.03 \%$. Due to the high correlation between traded volume and invoicing, and because of compatibility between the aspects to be discussed in the results, it was decided to use only the traded volume, inasmuch as such an option was supported by a previous analysis that showed no difference between using one or another variable.

The collected data was analyzed through variable grouping by similarity or the cluster analysis statistic method. According to Hair et al. (1998), cluster analysis is a technique for classifying objects in groups that show internal homogeneous characteristics and heterogeneous characteristics relative to one another. This allows the researcher to identify group profiles in the observed population.

The main techniques employed in group classifications based on the dataset are known as hierarchic and nonhierarchic methods (Hair et al., 1998), and the main difference between the two techniques is that the number of desired groups must be previously established at the non-hierarchic level. On the other hand, the groups classified through hierarchic techniques are a result of the available data (Mingoti, 2005).

The evaluation of beef trade was implemented in early studies through data grouping, leading to important information concerning habits and preferences of consumers, such as the frequency and place of purchase, trends of consumption for a product type, origin and quality, 
Table 1 - Share of the main beef exporters in international trade from 1994 to 2007

\begin{tabular}{lc}
\hline Country & $\%$ \\
\hline Australia & 21.34 \\
Brazil & 15.70 \\
United States of America & 13.72 \\
European Union-15 (EU-15)* & 10.17 \\
New Zealand & 8.59 \\
Canada & 7.51 \\
Argentina & 7.30 \\
India & 6.08 \\
Uruguay & 4.33 \\
China & 1.12 \\
Subtotal & 95.86 \\
Others countries & 4.14 \\
\hline
\end{tabular}

Source: organized from USDA (2007) data.

* For all observations, the 15 (fifteen) countries that constituted the European Union (EU) in 1995 were considered in the present research.

and consciousness regarding nutritional and sanitary values (Bernues et al., 2003; McCarthy \& Henson, 2005; Oliver et al., 2006; McCarthy et al., 2007; Schnettler et al., 2008; Velho et al., 2009; Vidal et al., 2008).

All analyses were performed using the statistics software SPSS ${ }^{\circledR} 13.0$ for Windows (SPSS, 2008a). The procedures consisted of descriptive data analysis, identification of colinearity, and data processing through the Twosteps ${ }^{\circledR}$ algorithm, which is designed for large groups of data with categorical and numerical variables (SPPS, 2008b). The Twosteps algorithm classifies clusters in a hierarchic pattern. The first step consists of evaluation of each data, allocating the registrations in pre-formed clusters. Alternatively, a new group is created according to the logarithmical distance. The distance between two clusters is related to the decrease in log-likelihood inasmuch as they are combined into one cluster. For calculating log-likelihood, normal distributions for continuous variables and multinomial distributions for categorical variables are assumed. It is also assumed that the variables are independent of each other, and so are the cases (SPSS, 2008b).

In the second step, the initial groups are refined, aiming at increasing the distance and forming a number of homogeneous groups as small as possible (SPSS, 2008b). The number of clusters can be determined by Information Criterion of Akaike (ICA) or Bayesian Criterion of Schwarz (BIC), one opting for the second because it is stricter with non-parametric data (Wolfinger, 1993).

Data processing through the Twosteps algorithm was performed by allocating categories such as observation period, exporting country and importing country in the space reserved for categorical variables, and traded volume and prices in US dollars by tons at the space reserved for continuous variables. Algorithm execution gave rise to two clusters, which were named CL1 and CL2. SSPS software was also used to perform regression tests, mean differentiation tests, and descriptive analysis of variables. This algorithm is recommended for analyzing large amounts of data with categorical and numerical variables, such as the variables used in the present study.

Finally, a data analysis and mining program named SPHINX ${ }^{\circledR}$ was used, wherein data modeling grouped elements that did not contribute individually to at least $2 \%$ of the total traded volume into a cluster named "Others". This program allowed for the analysis of individual and collective clusters and the development of charts and a variable distribution map. These charts and map make it possible to geographically visualize the proximity of such variables. The variable distribution map was built through crossing the charts corresponding to EC, IC, CLs, and P\$T (the latter being stratified into three categories, in which a price interval corresponded to approximately $1 / 3$ of the sum of TV on the sample).

\section{Results and Discussion}

With the exclusion of the General Agreement on Tariffs and Trades (GATT) in 1994, international trade began to be ruled by the World Trade Organization (WTO). This organization was established in the last round of negotiation at GATT - which became known as the Uruguay Round (UR) - with the purpose of liberalizing the international trade, to be a Forum for negotiating trade agreements and an arbitration forum for litigious trades among its members (WTO, 2008a).

For farming, the negotiations at the Uruguay Round have produced agreements that determined that developed countries should restrict domestic subsidies for production and exportation, setting goals of execution, the same being true for the importation taxes of agricultural products. It was also determined that the developed countries should guarantee the establishment of a minimal quota for agricultural products resultant from less developed countries economies and that non-tariff barriers would be replaced by tariffs (WTO, 2008b).

The international trade after the Uruguay Round grew significantly (DESA/UNSD, 2008), a fact that cleared out for beef once frozen boneless beef international trade grew approximately 72\% from 1994 to 2006 and enlivened by approximately 30 million tons, generating US\$ 74.4 billion in income. This volume of trade corresponded to $62.5 \%$ of the total fresh beef exported over the period and to $50.5 \%$ of invoicing.

Out of the 10 exporting countries in the analysis, 8 were responsible for $98 \%$ of FBB exports. In contrast, individual 
participation of these countries in the market varied substantially over the years. Amongst those countries demonstrating substantial variation, Brazil was distinguished, prior to 1998, as among the least expressive suppliers (Figure 1). Since then, Brazilian exportations have gradually increased, supported by a wide range of factors such as an increase in production and in the national herd (USDA, 2007), the intensification of trade relations with the EU-15, Russia, and Egypt, and the currency devaluation in January, 1999, which made Brazilian agricultural commodities financially more attractive for importers (USDA, 2000a; Gonçalves, 2005).

Brazilian export growth was stimulated by EU-15 export reductions, as the EU-15 recently decreased its production and herd size significantly. This is partially associated with the Bovine Spongiform Encephalopaty (BSE) and Foot and Mouth Disease (FMD) outbreaks in its territory, which led to a great number of animals being slaughtered in order to maintain the sanitary status next to World Organization for Animal Health (OIE) (Chalus, 2000; USDA, 2000b; USDA, 2001). This decline in EU-15 exports allowed its traditional customers, such as Russia, Egypt, and Iran to turn to Brazil for the necessary amount of frozen boneless beef to meet their demand. India was also benefitted, with the commercial opening that took place subsequently to the Uruguay Round. Exports of India increased by about $500 \%$ due to an increase in beef consumption (FAOSTAT, 2008) and the income of expressive customers like the Philippines, Malaysia, Angola, and Jordan (WORLD BANK, 2008a). Another development in the international system was the abrupt reduction in North American exports in 2004, which occurred because of a Bovine Spongiform Encephalopaty outbreak, leading to a loss of 70 customers (USDA, 2004), which demand a huge volume of beef, such as Japan, South Korea, Canada, and Mexico (Sparling \& Caswell, 2006; Marsh et al., 2008).

Concerning importers, of the 211 countries participating in this trade, 11 Importing Countries (IC) were identified, which collectively accounted for around $76 \%$ of frozen boneless beef operations in the international market from 1994 to 2006 (Figure 2). Performance variation of 6 of the main meat importers, showed falls of $16 \%$ and $62 \%$ in imports to Japan and Canada, respectively, and rises of 900, 109, and 53\% to Russia, Egypt, and United States of America (USA), respectively (Figure 3).

By analyzing Russian participation over the period, in 1999 the ascending movement that started in 1995 was interrupted, leading to a negative trend that continued until 2000, which also coincided with the serious Russian economical crisis that began in 1998 and continued until 2000 (Aslund, 2001; Basdevant \& Hall, 2002). In 2001, Russian purchases recovered to a high level, sustained in large part by the rise in petroleum exports (Basdevant $\&$ Hall, 2002), up to the point where, by 2006, Russia outpaced the USA as the greatest Frozen Boneless Beef importing country.

Nevertheless, this commercial opening was not the only factor behind the rise in beef imports by Russia. The reduction in livestock size that began after the Union of Soviet Socialist Republics dissolution was also associated with this event, in part because of the extinction of agricultural contributions received during the Cold War (Segrillo, 2000).

Since 1999, the USA kept their frozen boneless beef imports increasing, but in 2004, this upward trajectory was interrupted by the same occurrences that caused a fall in their exports (Figure 3), the loss of good customers due to the bovine spongiform encephalopathy disease outbreak, which was associated with both the reduction in internal consumption and increased domestic stocks of the product, reducing importation. The bovine spongiform encephalopathy outbreak in the USA was an additional factor contributing to a fall in Japanese imports, which were already declining because of a decrease in internal consumption. The rise in Egyptian imports, on the other hand, may be explained by an increase in beef consumption (FAOSTAT, 2008), which

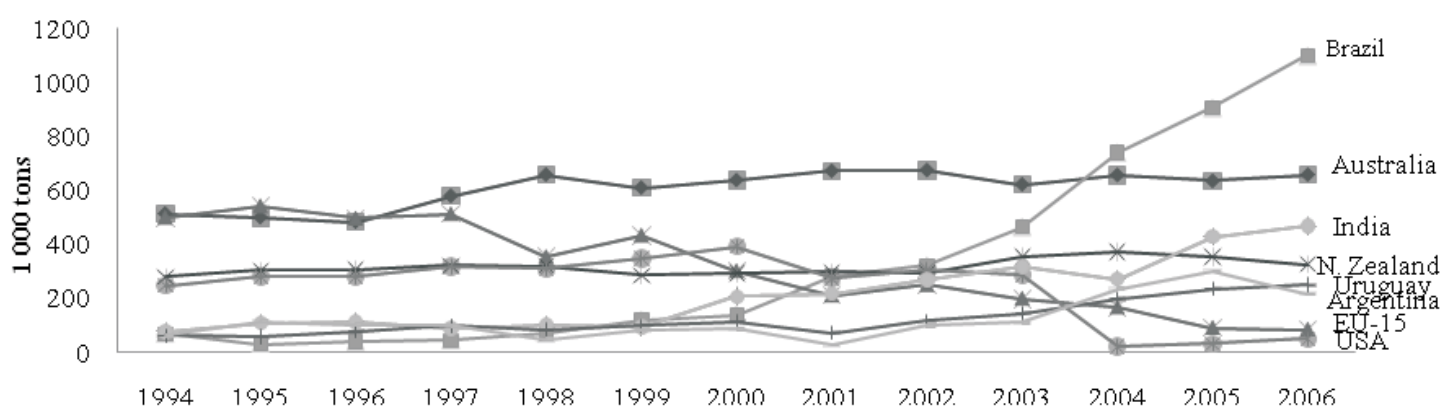

Figure 1 - Volumes traded by the main frozen boneless beef exporting countries from 1994 to 2006. 
is associated with an increase in the population income (WORLDBANK, 2008a).

This data and the employed methodology led to the identification of two clusters (Table 2). The descriptive analysis allowed the identification of each cluster profile and to consider as relevant the values found.

Based on the evaluation of statistical description of data (Table 2), it is possible to state that the traded volume and prices in US\$ per tons (P\$T) were different for both clusters, with the medians presented on the left side of the mean values, indicating an asymmetrical distribution of the data and a low prevalence of P\$T and traded volume transactions. The values of CL2 were the highest for both mean values, and the lowest variance was related to CL1 for frozen boneless beef market as a whole.

These deviations of observations around the means, with the latter displaced toward points outside the standard, do not necessarily mean that a given sample is either solid or problematic. Instead, this shows that the deviations must be observed in the context of analysis and evaluated in relation to the type of the provided information (Hair et al., 1998). Thus, it is possible to report that there is a great variation in both volume and prices used in exporting and importing operations in FBB international trade, with predomination of low-volume and high-price transactions.

When the clusters are analyzed in the global market (Figure 4), it is possible to identify that CL1 was placed in a position in the map where low prices prevail at the sample mean (Table 2). This figure shows that the distance between variables inversely represents the degree of prevalence on trade relations. That is, the shorter the distance between variables, the higher the relational degree between them. The lines that encircle variables are only illustrative, showing the concentration of the main agents in each cluster. In addition, the line that connects some agents shows that the transactional volume among them is higher than the expected value $(\mathrm{P}<0.05)$. The intersection of the axes represents the mean price of the sample, shaping quadrants where the top left limit corresponds to the minimal price, and the bottom left to the maximal price observed. So, it is understood that the negotiations performed at a price below the sample mean are placed in the south of intersectional axis, with the opposite applied to observations placed in the north of the intersectional point.

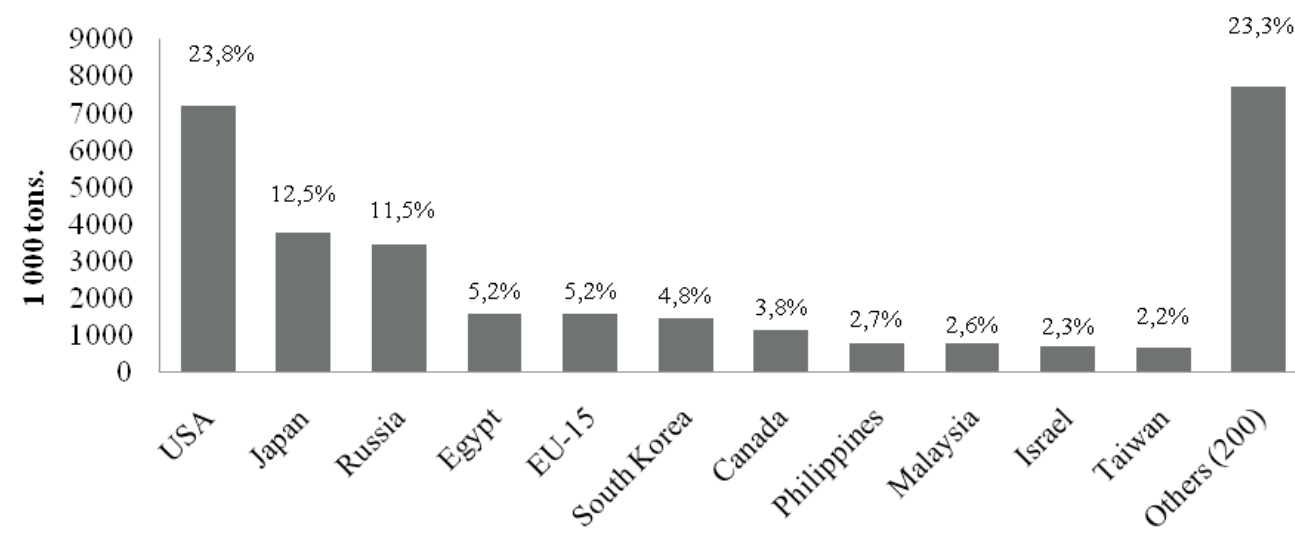

Figure 2 - Annual mean trade of frozen boneless beef and market participation of the main importing countries from 1994 to 2006.

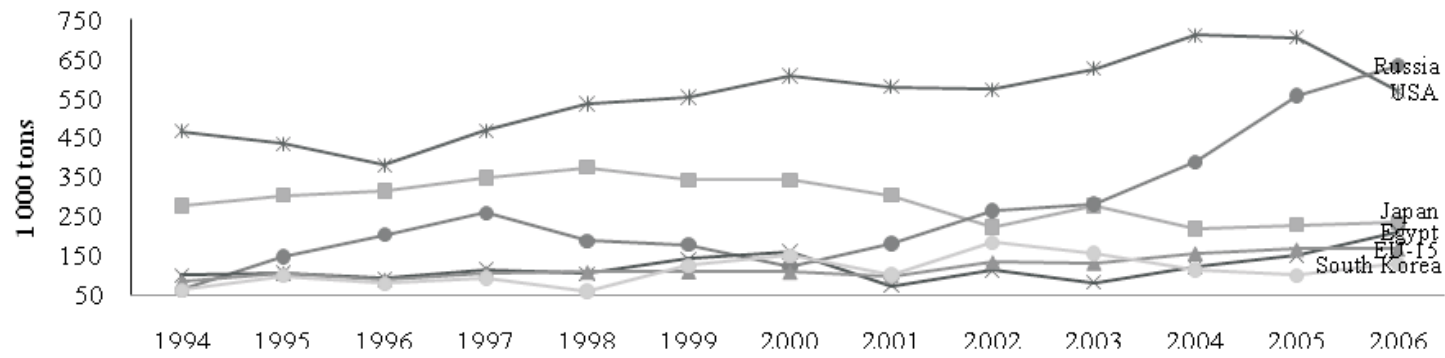

Figure 3 - Volumes traded by the main frozen boneless beef importing countries from 1994 to 2006. 
Table 2 - Descriptive analysis of variables

\begin{tabular}{cccccccc}
\hline Cluster & Variable & Totaltraded & Mean & Median & Minimum & Maximum & Standard deviation \\
\hline \multirow{2}{*}{1} & Traded volume & $8,556,837$ & 2,135 & 371 & 18 & 96,178 \\
& P\$/tons & & 1,977 & 1,727 & 205 & 18,274 \\
2 & Traded volume & 21,657 & 7,491 & 213 & 18 & 363,474 \\
& P\$/tons & 840 & 2,653 & 2,487 & 392 & 17,747 \\
\multirow{2}{*}{ Mean } & Traded volume & 30,214 & 5,679 & 280 & 18 & 363,474 \\
& P\$/tons & 677 & 2,462 & 2,304 & 205 & 18,274 \\
& & & & & 952 & 24,881 \\
\hline
\end{tabular}

Source: research results

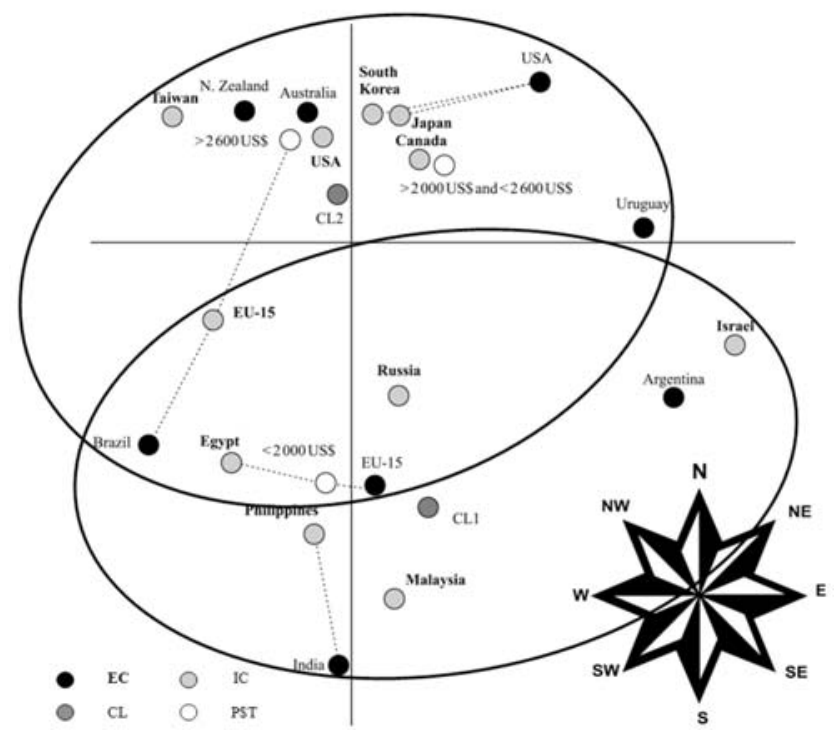

Figure 4 - Relationships among cluster, variables exporting country, importing country and price on frozen boneless beef international trade from 1994 to 2006 .

The distribution of the prices in the map may also exemplify the economic profile of these clusters importers, since among the importers listed on the map, most are countries that have the lowest per-capita income (WORLD BANK, 2008a). Additionally, presence of India is another factor leading to a price depression for CL1, because India is a country with low valorization of beef in the market because of the poor sanitary practices of most retail outlets and herds and also because beef is considered an inferior food, left to the lower castes (USDA, 1999, 2006a).

The presence of large importers in CL2, which have populations with high per-capita income (WORLD BANK, 2008b), favored the supremacy of high trade volumes and prices in US dollars by tons, as well as the concentration of $72 \%$ of frozen boneless beef. It is important to show the evidence that the variable disposition is not only due to the price range where operations were accomplished, but also due to trade volumes among the different agents that compose the market.
In this cluster, India, Brazil, Argentina, and EU-15 were classified as exporting countries. These countries diverge in their bovine breeding technologic development, but share a preference from low-income customers (Table 3). In total, 16 customers were identified as importers, which collectively corresponded to $74 \%$ of trade volumes in their cluster, and they were mostly countries whose populations have low to moderate incomes in comparison to international patterns (WORLD BANK, 2008b).

The bottom quadrants, in which trade operations at lower prices prevail, show 5 importing countries that import $25 \%$ of trade volumes in the cluster (Table 3 ). This includes their main supplier, India, a country with over 280 million animals in its population of livestock (USDA, 2006b), though it remains a deficient bovine breeder with low productivity indices, constant FMD outbreaks, and unknown risks for BSE (OIE, 2008).

In the Figure 5 the, distance between variables inversely represents the degree of prevalence in trade relations, that is, the shorter the distance between variables, the higher the relational degree between them. The line that connects some agents shows that the transactional volume among them is higher than the expected value $(\mathrm{P}<0,05)$. The intersection of axes represents the mean price of the sample, shaping quadrants where the top left limit corresponds to the minimum price, and the bottom left to the maximum price observed. Then, it is understood that the negotiations performed at a price below the sample mean are placed in the south of intersectional axis, the opposite applied to observations placed in the north of the intersectional point.

Iran, Russia, and South Africa are in the top left quadrant. These are importing countries that kept more expressive trade relations with EU-15 countries at operations whose prices prevailed above the mean of the cluster. On the right side of this group, there are customers whose imports from Brazil and Argentina prevailed, with prices higher than those of the rest of the cluster.

As it was previously mentioned, CL1 had the lowest market participation. In addition, it consisted of places with 
Table 3 - Quantitative characteristics of CL1

\begin{tabular}{lccc}
\hline Exporter & Trade volume/year & Prices in US dollars per tons & Cluster participation (\%) \\
\hline India & 212,737 & 1,323 & 32.3 \\
Brazil & 200,145 & 2,297 & 30.4 \\
EU-15 & 151,440 & 2,141 & 23.0 \\
Argentina & 93,894 & 2,505 & 14.3 \\
Importer & & & \\
EU-15 & 58,412 & 3,732 & 8.9 \\
Malaysia & 51,734 & 1,377 & 7.9 \\
The Philippines & 44,296 & 1,313 & 6.7 \\
Russian & 40,163 & 1,710 & 6.1 \\
Iran & 39,487 & 2,025 & 6.0 \\
Saudi Arabia & 34,419 & 1,856 & 5.2 \\
Israel & 33,993 & 2,330 & 5.2 \\
Egypt & 31,370 & 1,635 & 4.8 \\
United Arab Emirates & 28,877 & 1,507 & 4.4 \\
Algeria & 23,342 & 2,088 & 3.5 \\
Angola & 18,587 & 1,557 & 2.8 \\
Bulgaria & 17,208 & 1,584 & 2.6 \\
Chile & 16,745 & 1,954 & 2.5 \\
South Africa & 16,204 & 1,575 & 2.5 \\
Hong Kong & 15,317 & 2,384 & 2.3 \\
Jordan & 14,758 & 1,452 & 2.2 \\
Others & 173,307 & 1,996 & 26.3 \\
Total & 658,218 & & 100.0 \\
Sore: & & & \\
\end{tabular}

Source: research results

the lowest beef prices, partly justified by the economical development profile of predominantly low- and middleincome countries (WORLD BANK, 2008b), by the sanitary condition of their main exporters, and by the EU-15 export profile, which, regarding the price obtained in its FBB exports, must offer a product perceived as being of low quality for its local consumers.

This priority regarding the price is still more evident for importers that maintain frozen boneless beef trade with India, a country that shows the most unfavorable sanitary conditions among suppliers in this cluster. This is different from what is observed in countries that import from the EU-15, Argentina, or Brazil, which were also most countries that showed the highest economic development in the cluster. Thus, it is believed that CL1 has a less demanding customer profile regarding to sanitary conditions of suppliers, and whose low product prices are a conditional factor behind FBB import.

The cluster 02 is composed of six exporting countries (ECs), which are the USA, Australia, New Zealand, the EU-15, Brazil, and Uruguay (Table 4). The four first countries share similarities, as their populations possess a high percapita income (WORLD BANK, 2008b), they have highly productive breeding (FAOSTAT, 2008), and they all figure in the list of countries free of FMD without vaccinations. Of these countries, BSE outbreaks have already been reported in the USA and the EU-15, which caused a strong impact on beef exports in the former, leading to a suspension in beef exports to important customers like Japan, South Korea, and Hong-Kong (Mattson \& Koo, 2007; Schroeder et al., 2007; Marsh et al., 2008).

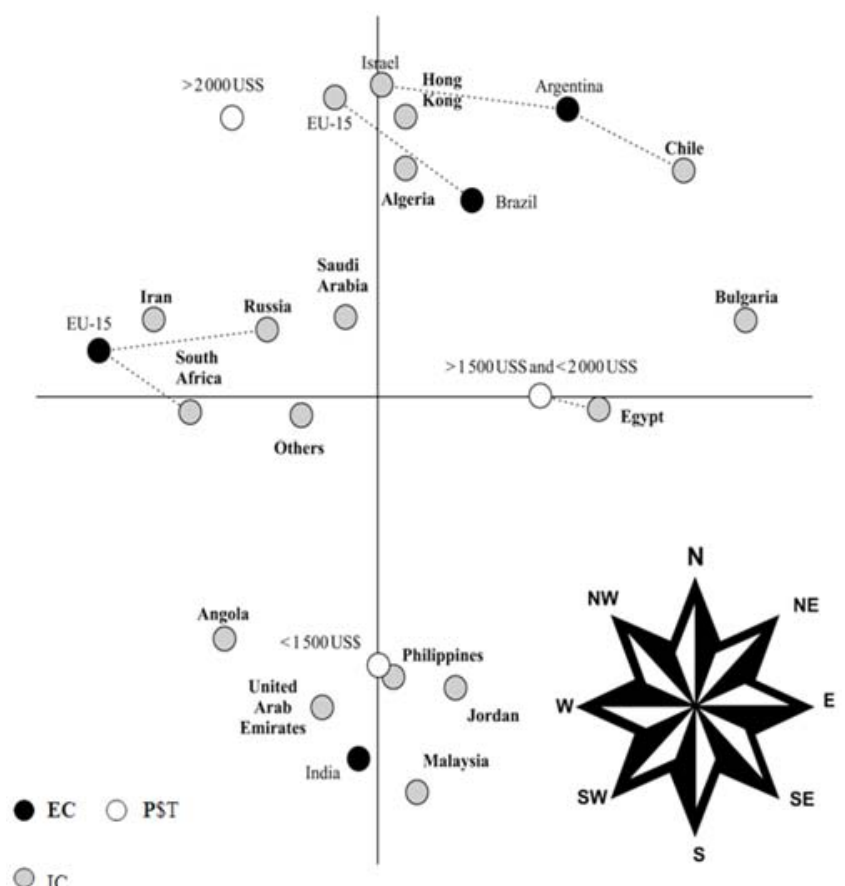

Figure 5 - Relationships among variables exporting country, importing country, price as components of cluster 1 in the international frozen boneless beef trade between 1994 and 2006. 
Brazil and Uruguay, in turn, which share a predominance of animals produced on pastures, have never registered BSE in their herds, and make use of vaccination to prevent FMD outbreaks, except Santa Catarina, a Brazilian state, which is considered a FMD free zone without vaccination. It is proper to highlight that, from the countries in this cluster that have never had BSE outbreaks in their territory, only Brazil does not fit among countries with minimal risk for this disease. For ICs, nine customers were classified which, in combination, accounted for $88 \%$ of imports in their cluster. These are mostly considered economically developed countries with a population that has high percapita income.

The trade relationships between these agents can be observed in the map of the distribution of variables (Figure 6), which shows, in the bottom, quadrants that Russia and Egypt have EU-15 and Brazil as their main suppliers, and a higher business prevalence amongst these two customers with the EU-15 at lower prices than those established with Brazil. Yet, in the southern half of the map, the EU-15 is found as an importing country, with Brazil as its main supplier, in which operations with prices above US $\$ 2,800$ prevail. This can be confirmed by the line indicating that the values observed for supplier and price are above the expected values $(\mathrm{P}<0.05)$.

In Figure 6, the distance between variables inversely represents the degree of prevalence of trade relationships. That is, the shorter the distance between variables, the higher the relational degree between them. The line that connects some agents shows that the transactional volume among them is higher than the expected value $(\mathrm{P}<0.05)$. The intersection of axes represents the mean price of the sample, shaping quadrants where the top left limit corresponds to the minimum price, and the bottom left to the maximum price observed. Then, it is understood that the negotiations performed at a price below the sample mean are placed in the south of intersectional axis, the opposite being applied to observations placed in the north of intersectional point.

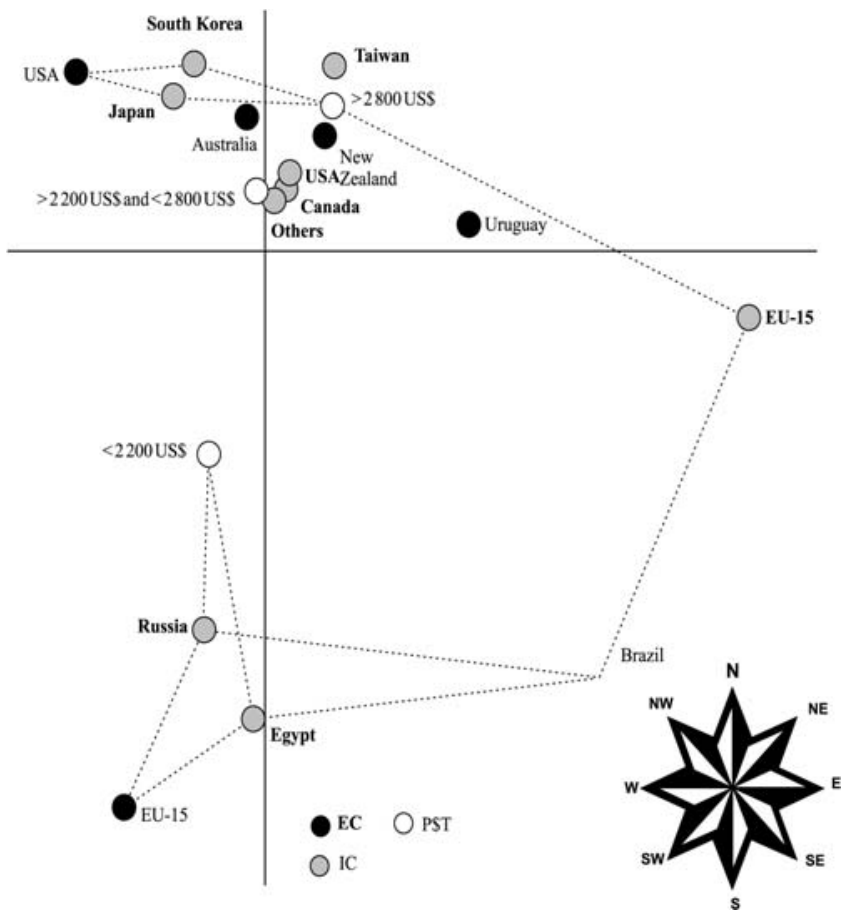

Figure 6 - Relationships between variables exporting country, importing country, price as components of cluster 2 in international frozen boneless beef trade from 1994 to 2006.

Table 4 - Quantitative characteristics of CL2

\begin{tabular}{lccc}
\hline Exporters & Trade volume/year & Prices in US dollars per tons & Cluster participation (\%) \\
\hline Australia & 607,122 & 2,485 & 36.4 \\
New Zealand & 315,982 & 2,722 & 19.0 \\
USA & 242,542 & 3,950 & 14.6 \\
EU-15 & 166,720 & 1,676 & 10.0 \\
Brazil & 132,752 & 2,414 & 8.0 \\
Uruguay & 123,951 & 2,587 & 7.4 \\
Importers & & & 32.9 \\
USA & 548,703 & 2,455 & 17.5 \\
Japan & 291,049 & 3,230 & 13.6 \\
Russia & 226,533 & 1,901 & 6.6 \\
South Korea & 110,418 & 3,541 & 5.4 \\
Egypt & 89,865 & 1,856 & 5.1 \\
Canada & 85,203 & 2,393 & 3.8 \\
EU-15 & 62,592 & 3,550 & 3.0 \\
Taiwan & 50,459 & 3,504 & 12.1 \\
Others & 201,165 & 2,655 & \\
Total & $1,665,988$ & & 100.0 \\
\hline Soure: & & &
\end{tabular}

Source: research results 
Regarding sanitary rules, the most exigent IC is the EU-15, which allows the entrance of beef only from FMD-free countries, with or without vaccination, which do not make use of growth hormones (Galbraith, 2002) and use auditable bovine traceability systems (EUR-LEX, 2000). Egypt and Russia, in turn, are restricted to licensed slaughterhouses and to the condition of FMD-free beef imports without vaccination (MAPA, 2006).

The customers in the top quadrants had more expressive trade relations with Australia, the USA, New Zealand, and Uruguay in commercial operations, where prices higher than the cluster mean values prevailed. It is observed that the importers with the highest economical power and the greatest suppliers that show the most favourable sanitary conditions are concentrated in quadrants of higher prices.

Additionally, a strong trade relationship between Japan and South Korea with the USA is verified in the top left quadrant, reflecting, in this map, the accumulated behavior of these agents over the analyzed period, which would have appeared very different if it was observed what had happened from 2004 because of the report of BSE in the North American territory.

Regarding sanitary conditions, the presence of Uruguay in the top right quadrant stands out because it is the only supplier above the middle line of prices that is not listed by OIE as an FMD-free country without vaccination. However, its presence in such position is due to its characterization as an important beef supplier to the USA and Canada, a condition that became possible in 2003, after Uruguay had its production system accredited by USA Department of Agriculture, which constituted a sine qua non condition for beef exports by that country (Rich, 2005).

Therefore, it can be stated that, at the top quadrants, the main factor that limits or motivates trade relationships are the sanitary aspects inasmuh as countries such as South Korea and Japan narrow beef imports to suppliers which use vaccination and FMD eradication, and whose risk of BSE infection next to OIE is minimal. Another exigency that comes from sanitary concerns is the need for certification of productive processes to North-American guidelines and a traceability process accredited not only by the American government, but also by the European Union sanitary committee(EUR-LEX, 2000; USDA, 2008).

Under such scenario, and due to the greatest participation of the cluster of countries in quadrants whose FBB prices are higher than the cluster mean values, the prerogatives which establish trade relations for CL2 are supported primarily by the sanitary condition to which the livestock are exposed to, leaving the price as a secondary factor.

\section{Conclusions}

Frozen boneless beef international trade is composed of two clusters representing two markets of different sizes and priorities. At Cluster 1, prerogatives that establish relationship between suppliers and customers primarily involve price of product, and, to a lesser degree, sanitary requirements. At Cluster 2, traded volumes were larger and the priority for the supplier was the sanitary condition of livestock, with price placed on a secondary position. Due to the traded volume, the United States of America figure as the most expressive customer and Brazil is the most expressive exporter, especially for those where price is the leading import condition. Not being found as relevant in publications on Frozen Boneless Beef, has limited the discussion of comparative character with findings by other authors, so such commodity is analyzed by other perspective and methodologies such as application of questionnaires and interviews with authorities and agents who work in this market.

\section{References}

ALICEWEB. Ministério do Desenvolvimento Indústria e Comércio. [2008]. Disponível em: <http://aliceweb.desenvolvimento.gov.br/>. Acesso em: 5/3/2008.

ASLUND, A. Russian crisis and its effects. Journal of Comparative Economics, v.29 n.2, p.389-390, 2001.

BASDEVANT, O.; HALL, S.G. The 1998 Russian crisis: could the exchange rate volatility have predicted it? Journal of Policy Modeling, v.24, n.2, p.151-168, 2002.

BERNUES, A.; OLAIZOLA, A.; CORCORAN, K. Extrinsic attributes of red meat as indicators of quality in Europe: an application for market segmentation. Food Quality and Preference, v.14, n.4, p.265-276. 2003.

BUREAU OF LABOR STATISTICS - BLS. [2008]. Disponível em: <www.bls.gov/data/>. Acesso em: 17/7/2008.

CENTRO DE ESTUDOS AVANÇADOS EM ECONOMIA APLICADA - CEPEA. [2008]. Índices regionais e nacionais de exportação do agronegócio. Disponível em: <http:// www.cepea.esalq.usp.br/macro/>. Acesso em: 19/7/2008.

CHALUS, T.; PEUTZ, I. BSE: the European regulatory context. Euro Surveillance, v.5, n.10, p.107-114, 2000.

EUR-LEX, Regulation (EC) no 1760/2000 of the european parliament and of the council of 17 July 2000 establishing a system for the identification and registration of bovine animals and regarding the labelling of beef and beef productsand repealing Council Regulation (EC) No820/97. 2000. Disponível em: <http://eurlex.europa.eu/LexUriServ/LexUriServ.do?uri=OJ:L:2000:204:0001: 0010:EN:PDF>. Acesso em: 4/8/2008.

FOOD AND AGRICULTURE ORGANIZATION OF THE UNITED NATIONS STATISTICS - FAOSTAT. [2008]. Disponível em: $<$ http://faostat.org/degault.aspx> Acesso em: 19/5/2008.

GALBRAITH, H. Hormones in international meat production: biological, sociological and consumer issues. Nutrition Research Reviews, v.15, n.2, p.293-314, 2002.

GONÇALVES, J.S. Real apreciado, câmbio flutuante e agronegócios. [2005]. Disponível em: <http://www.iea.sp.gov.br/ out/verTexto.php?codTexto=2486>. Acesso em: 20/7/2008. 
HAIR, J.F.; ANDERSON, R.E.; TATHAM, R.L. et al. Multivariate data analysis. 5.ed. New Jersey: Prentice Hall, 1998. 768p.

INTERNATIONAL ORGANIZATION FOR STANDARTIZATION (ISO). [2008]. Disponível em: <http://www.iso.org>. Acesso em: $12 / 8 / 2008$.

MARSH, J.M.; BRESTER, G.W.; SMITH, V.H. Effects of North American BSE events on U.S. cattle prices. Review of Agricultural Economics, v.30, n.1, p.136-150, 2008.

MATTSON, J.W.; KOO, W.W. Effects of bovine spongiform encephalopathy outbreaks on US cattle and beef prices. Review of Agricultural Economics, v.29, n.4, p.734-748, 2007.

McCARTHY, M.; BRENNAN, M.; KELLY, A.L. et al. Who is at risk and what do they know? Segmenting a population on their food safety knowledge. Food Quality and Preference, v.18, n.2, p.205-217, 2007.

McCARTHY, M.; HENSON, S. Perceived risk and risk reduction strategies in the choice of beef by Irish consumers. Food Quality and Preference, v.16, n.5, p.435-445, 2005.

MINGOTI, S.A. Análise de dados através de métodos de estatística multivariada: uma abordagem aplicada. Belo Horizonte: Editora UFMG, 2005. 297p.

MINISTÉRIO DA AGRICULTURA PECUÁRIA E ABASTECIMENTO - MAPA. Circular No 41/2006/DIPOA. [2006]. Disponível em: <www.agricultura.gov.br>. Acesso em: $14 / 5 / 2008$.

OLIVER, M.A.; NUTE, G.R.; FONT I FURNOLS, M. et al. Eating quality of beef, from different production systems, assessed by German, Spanish and British consumers. Meat Science, v.74, n.3, p.435-442, 2006

RICH, K.M. Animal diseases and the cost of compliance with International Standards and Export Markets. The experience of foot-and-mouth disease in the Southern Cone. The World Bank. [2005]. Disponível em: <http://siteresources. worldbank.org/INTRANETTRADE/Resources/Topics/Standards/ FMDMercosurF.pdf.> Acesso em: 16/8/2008.

SCHNETTLER, B.; VIDAL, L.M.; SILVA, R.F. et al. Consumer perception of animal welfare and livestock production in the Araucania Region, Chile. Chilean Journal of Agricultural Research, v.68, n.1, p.80-93, 2008.

SCHROEDER, T.C.; GLYNN, T.T.; PENNINGS, J.M.E. Consumer food safety risk perception and attitudes: Impacts on beef consumption across countries. B.E. Journal of Economic Analysis and Policy, v.7, n.1, p.1-29, 2007.

SEGRILLO, A. O fim da URSS e a nova Rússia: de Gorbachev ao pós-Yeltsin. Petrópolis: Vozes, 2000. 152p.

SPARLING, D.H.; CASWELL, J.A. Risking market integration without regulatory integration: The case of NAFTA and BSE. Review of Agricultural Economics, v.28, n.2, p.212-228, 2006.

STATISTICAL PACKAGE FOR SOCIAL SCIENCES - SPSS. [2008a]. Disponível em: <http://www.spss.com.br>. Acesso em: $15 / 1 / 2008$

STATISTICAL PACKAGE FOR SOCIAL SCIENCES - SPSS. The SPSS twosteps cluster component. [2008b]. Disponível em: <ftp://ftp.spss.com/pub/web/wp/TSCWP-0101.pdf> Acesso em: 25/1/2008

UNITED STATES DEPARTMENT OF AGRICULTURE - USDA. Indian livestock annual 1999. [1999]. Disponível em: <http://www.fas.usda.gov/gainfiles/199907/25475398.pdf>. Acesso em: 10/2/2008.

UNITED NATIONS COMMODITY TRADE STATISTICS DATABASE - DESA/UNSD. [2008a]. Disponível em: <http://comtrade.un.org/db>. Acesso em: 26/4/2008.

UNITED STATES DEPARTMENT OF AGRICULTURE - USDA. Cattle and beef. [2000a]. Disponível em: <http:// www.fas.usda.gov/dlp2/circular/2000/00-03LP/beef.htm>. Acesso em: 15/4/2008.

UNITED STATES DEPARTMENT OF AGRICULTURE - USDA Brazil dairy and livestock and poultry annual livestock report. [2000b]. Disponível em:<http://www.fas.usda.gov/ gainfiles/199908/25475491.pdf >. Acesso em: 10/4/2008.

UNITED STATES DEPARTMENT OF AGRICULTURE - USDA. Meat situation in the European Union in 2002. [2001]. Disponível em: <http://www.fas.usda.gov/dlp2/circular/2001/ 01-10LP/EUmeat.html>. Acesso em: 10/4/2008.

UNITED STATES DEPARTMENT OF AGRICULTURE - USDA World beef overview. [2004]. Disponível em: <http:// www.fas.usda.gov/dlp2/circular/2004/04-03LP/beefoverview.html>. Acesso em: 10/4/2008.

UNITED STATES DEPARTMENT OF AGRICULTURE - USDA. India livestock and products annual livestock report 2006. [2006]. Disponível em: <http://www.fas.usda.gov/ gainfiles/200608/146208726.pdf>. Acesso em: 10/4/2008.

UNITED STATES DEPARTMENT OF AGRICULTURE - USDA. Livestock and poultry world markets and trade. [2007]. Disponível em: <http://www.fas.usda.gov/dlp/circular/2007/ livestock_poultry_11-2007.pdf>. Acesso em: 9/4/2008.

UNITED STATES DEPARTMENT OF AGRICULTURE - USDA. H. R. 6124. [2008]. Disponível em: <http://www.usda.gov/ documents/Bill_6124.pdf>. Acesso em: 9/4/2008.

VELHO, J.P.; BARCELLOS, J.O.J.; LENGLER, L. et al. Disposição dos consumidores porto-alegrenses à compra de carne bovina com certificação. Revista Brasileira de Zootecnia, v.38, n.2, p.399-404, 2009

WOLFINGER, R.D. Covariance structure in general mixed models. Communications in Statistics, v.22B, p.1079-1106, 1993.

WORLD ORGANISATION FOR ANIMAL HEALTH - OIE. [2008a]. Terrestrial animal health code 2008. Disponível em: <http://www.oie.int/eng/normes/mcode/en_sommaire.htm> Acesso em: 18/4/2008.

WORLD BANK. Data \& statistics. [2008a]. Disponível em: <http:/ /web.worldbank.org/WBSITE/EXTERNAL/DATASTATISTICS/ 0,,contentMDK:20535285 menuPK:1192694 pagePK:64133150 piPK:64133175 theSitePK:239419,00.html>. Acesso em: 15/3/2008.

WORLD BANK. Data \& statistics: country groups. [2008b]. Disponível em: <http://web.worldbank.org/WBSITE/EXTERNAL /DATASTATISTICS / 0 contentMDK:20421402 pagePK: 64133150 piPK:64133175 theSitePK:239419,00.html\#Low_ income>. Acesso em: 5/4/2008.

WORLD TRADE ORGANIZATION - WTO. What is the World Trade Organization? [2008a]. Disponível em: <http:// www.wto.org/english/thewto_e/whatis_e/tif_e/fact1_e.htm>. Acesso em: 6/4/2008.

WORLD TRADE ORGANIZATION - WTO.. Legal text: the WTO agreement. [2008b]. Disponível em: <http://www.wto.org/ english/docs_e/legal_e/ursum_e.htm> Acesso em: 23/4/2008. 